\title{
The Function of Class Teacher Educational Management in Improving Student's Learning Outcomes
}

\author{
Erisna Yunita \\ SD Negeri 3 Babat Toman \\ e-mail: erisnayunita6606@gmail.com \\ Yasir Arafat \\ Universitas PGRI Palembang \\ e-mail: yasir_arafat14@yahoo.com \\ Mulyadi \\ Universitas PGRI Palembang \\ e-mail: mulyadi@univpgri-palembang.ac.id \\ Article History: Received on 30 September 2020, Revised on 10 October 2020, \\ Published on 12 October 2020
}

\begin{abstract}
The purpose of this research was to determine the function of classroom teacher education management in improving student learning outcomes of SD Negeri in Babat Toman District, Musi Banyuasin Regency. This research is a qualitative research, with the aim of being able to gain an in-depth understanding and interpretation of the meaning of the phenomena in the field. The function of classroom teacher education management in improving student learning outcomes of SD Negeri in Babat Toman Subdistrict, Musi Banyuasin Regency can be said to be good and in accordance with the duties assigned in carrying out the learning process.
\end{abstract}

Keywords: Function of Class Teacher, Educational Management, Student's Learning Outcomes

\section{A. Introduction}

School is one of the factors that determine student learning outcomes. The higher the student's learning ability and the quality of teaching at school, the higher the student's learning outcomes (Wasliman, 2014). A teacher has a moral obligation to society that he carries out his duties with effort, honesty and seriousness which cannot be negotiated. From this, we can understand that just armed with knowledge no matter how great it is not enough to be able to call yourself a teacher. Education in general aims to develop student potential. As a good teacher, it is natural that he wants as many of his students as possible to pass or get good grades. He will be unhappy if many of his students score less or don't pass. In this case, teachers are expected to develop children's potential, must be clever in limiting themselves so that their desire to produce children with high scores (Sukadi, 2012).

According to Susanto (2016), the teacher is a very decisive component in the implementation of a learning strategy. Based on this opinion, it can be emphasized that one of the external factors that greatly affects student learning outcomes is the teacher. The teacher in the learning process plays a very important role. The role of the teacher, especially for students at elementary school age, cannot possibly be replaced by other devices such as television, radio 
and computers. Because students are developing organisms that need adult guidance and help.

The problem of education and teaching is a fairly complex problem where many factors influence it. One of these factors is the teacher. The teacher is a teaching component that plays an important and major role, because the teaching and learning process is very much determined by the teacher factor. The teacher's task is to deliver subject matter to students through communication interactions in the teaching and learning process, where the success of the teacher in delivering material is very dependent on the smoothness of communication interactions that have an effect on the message given by the teacher (Hamid, 2015).

The teacher is one of the most important elements in education. The quality of education is very much determined by the quality standards of teachers. Therefore, teachers need to improve their competence as stated in Law Number 14 of 2005 concerning Teachers and Lecturers. There are four competencies that teachers must fulfill, namely pedagogical competence, personality, professional competence and social competence. Then what about the teacher competency standards in Indonesia, do they meet the four competencies above. Of course there must be concrete steps to improve the quality and competence of teachers. The Ministry of Education and Culture realizes this and anticipates it by mapping teacher competency standards in Indonesia. Various trainings to improve teacher competence have been carried out, including teaching training adapted to current developments such as the use of technology.

Being a teacher is not like a politician who is good at building promises or a comedian who is required to make his audience laugh and be entertained. Being a teacher can be a "lamp" that illuminates the darkness of thinking and satisfies the hunger and curiosity of students. Being a teacher cannot be with reasons. The task of a teacher is not only to carry out learning from a pile of theories and knowledge and doctors but must be able to carry out learning that stimulates the activities and potential of students according to their respective capacities. But the main task of a teacher is to educate, which means that the teacher does not only share knowledge with students but educates students in terms of attitudes and actions (Rizaldi, 2014).

The quality of teachers in teaching is one important aspect in efforts to improve the quality of life of the nation. This is because the source of teachers is the main force for all efforts to educate and learn the nation's children. This ability does not just exist, but is obtained from a long process of education and learning. With this process, we can obtain competent figures in their fields and then this changes the conditions of a general problem (Usman, 2012).

Efforts to improve teacher quality have been carried out by the government in various ways, including by providing block grants to schools as stimulant funds for implementing teacher professional development programs, forming subject teacher associations, forming teacher scientific forum organizations and publishing scientific journals. for teachers and teachers using the Subject Teacher Deliberation Program (MGMP) which has been in existence in almost every district. These various teacher quality development programs mainly aim to improve the abilities and skills of teachers in planning, developing, implementing and supervising the learning process to support improving the quality of education in each school unit (Sumardin, 2016). 
Classroom management is an aspect of education that is often the main concern of prospective teachers, new teachers, and even experienced teachers who want students to learn optimally. The creation of such expectations is a study of classroom management. Because according to Djamarah and Zain (2010). Classroom management is a complex behavioral problem, and teachers use it to create and maintain classroom conditions in such a way that students can achieve teaching goals efficiently and enable them to learn.

Danim (2012) explains that it is in class that all aspects of learning meet and have a process. Teachers with all their abilities, students with all backgrounds and potentials, the curriculum with all its components, the method with its approach, the media with all its tools, the material with all its learning resources meet and interact in the classroom. Furthermore, learning outcomes are also determined by what happens in class. Therefore, it is proper that the classes in management are good, professional, continuous and sustainable. The positive relationship between teachers and students only builds with a positive attitude. Even though there are weaknesses in students, of course there are many advantages and it is far better to develop positive potential in students than to look for their weaknesses.

Teachers have a very big share of the success of learning in schools. Teachers are very instrumental in helping the development of students to achieve their life goals optimally. Every teacher enters the class, so at that time he also faces two main problems, according to Djamarah and Zain (2012), namely: teaching problems and management problems. Teaching problems are efforts to assist students in achieving specific teaching goals directly, for example making lesson units, presenting information, asking questions, evaluating. Meanwhile, the problem of management is an effort to create and maintain conditions in such a way that the teaching and learning process can take place effectively and efficiently, for example strengthening members, developing teacher-student relationships, making productive group rules.

Danim (2012) further argues that classroom management is not only in the form of class arrangements, physical facilities and routines. Class management activities are intended to create and maintain classroom atmosphere and conditions. So that the teaching and learning process can take place effectively and efficiently. For example, providing reinforcement, developing teacher-student relationships and making productive group rules. Class management is needed because from day to day, even from time to time, the students' behavior and actions are always changing. Today students can study well and calmly, but not necessarily tomorrow. Yesterday there was healthy competition in the group, on the other hand, in the future the competition may not be healthy. Classes are always dynamic in the form of students' behavior, deeds, attitudes, mental and emotional. Effective classroom management performance according to Danim (2012) is reflected in the success of teachers in creating positive learning environments and empowering students to understand and be effective in engaging in the classroom management process.

In teaching and learning activities, of course, a teacher becomes the center of attention and is responsible for directing and guiding students in every learning process that takes place. Usman (2012) as a teacher class manager is responsible for maintaining the physical environment of the class so that it is always fun to learn and directing or guiding the intellectual and social processes in the classroom. Thus the teacher not only allows students to learn, but also develops the habit of working together with other students. The success of teachers in carrying out learning activities does not only require the ability to master subject 
matter, teaching strategies and methods, using media or learning tools. But the teacher must be able to provide or create conducive and pleasant learning situations and conditions that can be realized if the teacher is able to regulate the learning atmosphere, condition students to learn and take advantage of learning facilities or media and can control a pleasant atmosphere to achieve learning goals, this ability is called ability. manage the class.

Classroom management activities are activities that are closely related to learning activities and are very important in order to achieve an effective learning process. In the Big Indonesian Dictionary, the term management is defined as "administration, management". Meanwhile, what is meant by class is "level, the space for learning at school. So that class management is translated briefly as a process of organizing or managing a room where teaching and learning activities are carried out. Classroom management is needed because from day to day and even from time to time, the behavior and actions of students are always changing. Today students can study well and calmly, but not necessarily tomorrow. Yesterday there was healthy competition in the group, in the future the competition may not be healthy. Therefore, in managing the classroom, a teacher certainly needs to pay attention to how to create an appropriate learning climate, organize learning spaces, and manage teaching and learning activities so that teaching and learning activities can run according to predetermined goals.

According to Wahyuningrum (2014), there are three core activities in classroom management, namely as follows: 1) creating the right learning climate including warmth and enthusiasm, challenges, variety, flexibility, emphasis on positive things, and cultivation of self-discipline. 2) arranging the learning room including the seating arrangement of students, the arrangement of educational media, the provision of aromatherapy. and 3) managing teaching and learning activities including opening and closing lessons skills, explaining skills, questioning skills, reinforcement skills, learning media skills, small group discussion guiding skills, class management skills, variation skills and individual and small group teaching skills.

In the school environment students are subjects and objects that require guidance from others to direct their potential and guidance towards maturity with character. With continuous character building, it is expected to form students with character. Students who have good character are able to become positive norms and values that affect the student's education (Kurniawan, 2016).

Ngalim (2014) argues that there is a strong tendency that to improve the quality of service in the quality of teaching teachers what needs to be nurtured and reorganized is their ability, so that in turn it can be used to direct teacher programs to become professional figures in education. In carrying out their duties, a teacher provides support who can carry out their duties well as educators and teachers. As professional teachers, they must have special skills and be able to master the intricacies of education and teaching with various sciences that need to be nurtured and developed through a certain education period.

In carrying out their duties, teachers are not in an empty environment. It is part of a "great machine" of national education, and so it is bound by nationally established guidelines for what to do. It is as usual anywhere, but in the context of teacher professionalism where teaching is considered a professional job, teachers are required to be professional in carrying out their duties. In other words, teachers are able to manage the classroom well, create a 
harmonious climate, and are able to deliver active, innovative, creative, effective and fun learning (Sani, 2017).

In Babat Toman Subdistrict, Musi Banyuasin Regency, there are 6 (six) Public Elementary Schools with 36 class teachers. In the learning process activities of each State Elementary School in Babat Toman District, Musi Banyuasin Regency, it is carried out in the morning. The learning process is very tight and in accordance with the schedule and curriculum that is enforced. Each State Elementary School in Babat Toman Subdistrict, Musi Banyuasin Regency has 6 (six) study groups consisting of class I (1 class), class II (1 class), class III (1 class), class IV (1 class), class V (1 class), and class VI (1 class). Meanwhile, extracurricular activities are only carried out on Wednesdays and Saturdays starting from 15.00 WIB to 17.00 WIB.

Based on the information the researchers obtained from each school, it was explained that each class teacher had provided learning to students in accordance with the learning device curriculum that had been prepared, but not all teachers were able to manage the class well, because the teacher's abilities varied. As the school leader, he always tries to improve the quality of teachers in managing the class. However, the obstacles faced are the lack of teachers' ability to manage the class, the lack of training for teachers to attend training and seminars. This has always been the principal's homework material to always provide the best for class teachers, such as proposing teachers to attend KKG so that the quality of teachers in managing the class is even better. Given the very rapid development of technology and a need for reliable and professional teachers. The school principal also added his statement that not all teachers who taught were able to implement teaching using Curriculum 13, because so far the teachers used KTSP, while the directions from the Ministry of National Education of the Republic of Indonesia and the Banyuasin District Education Office for each school must be guided by Curriculum 13 .

Based on the description of the background of the problem above, the researcher was moved to find out more about the development of student achievement through the management function of classroom teacher education at the Babat Toman Elementary School, Musi Banyuasin District. This research is based on relevant studies and strengthens researchers to study this research, such as research conducted by Sudrajat (2018) with the research title Primary School Teacher Performance Management. Furthermore, research conducted by Feri (2017) with the title of research Teacher Learning Management at SD Negeri 1 Pelukan Pidie, Pidie Regency, and Muningsih (2015) with the title Classroom Management for Elementary School Teachers (Study of Learning Analysis Students of SDN 02 Curup Timur).

\section{B. Methods}

This research is a qualitative research, with the aim of being able to gain an in-depth understanding and interpretation of the meaning of the phenomena in the field. Moleong (2011) argues that research that has qualitative research is research that is conducted by observing, and is carried out in a natural setting or overall context, and the main data collection tool is research itself. Furthermore, Sudaryono (2012) suggests that the research method is the way to achieve goals. Sources of research data came from teachers of SD N Sereka, SDN 1 Mangunjaya, SDN 2 Mangunjaya, SDN 2 Babat, SDN 4 Babat, SDN Muara Punjung. The data that will be taken to be used as research material are the results of interviews with teachers and school principals as well as the results of research permit 
documentation, research photos and other supporting sources. The research instrument was an interview guide. Analysis of the qualitative data used in this study as stated by Sugiyono (2015), which uses three stages: 1) data reduction, 2) data display or presentation, and 3) conclusions and data verification.

\section{Results and Discussion}

Based on the results of the study, it can be said that the management of classroom teacher education in improving student learning outcomes of SD Negeri in Babat Toman District, Musi Banyuasin Regency can be said to be good and in accordance with its function as a teacher who provides learning material. Based on the results of research through the results of interviews with each school principal, it was found that the principal said that the teacher in planning learning could be said to be good, because it was according to what was suggested, which must refer to the set curriculum. The principal said that the teacher could be said to be good at carrying out the learning as suggested, which must be based on the established curriculum. Besides that, it is also recommended that teachers in delivering learning materials must refer to Basic Competencies and Core Competencies.

The school principal said that he had given directions to the teachers to evaluate the learning process both mid-semester, per semester and at the end of the year. The principal said that the teacher's ability to manage learning tools was said to be good. Because so far the learning process delivered has referred to the RPP. The principal said that the teacher's ability to manage students was good, because during the learning process the teacher had conveyed through a persuasive approach. This is done because students are still considered children.

The principal said that the teacher's ability to manage student learning facilities was already good. Because during the learning process that is delivered, the teacher always reminds students to always bring textbooks and complete learning tools. Besides that, teachers also use teaching aids as teaching aids. The principal said that the teacher's ability to create and maintain learning conditions was good. This is evident from the learning process conveyed by the teacher can activate student learning and the learning process runs effectively and efficiently.

The principal said that the teacher's ability to control learning conditions was good. It is known by the principal when supervising class visits, that the teacher can create an active learning atmosphere. Students can absorb the learning material presented. The principal said that the teacher's ability to overcome student learning difficulties was good. This is evident from students who often ask the teacher if there is learning material that is not understood and the teacher explains to these students, such as mathematics learning material, where not all students are able to absorb the material. The principal said that the teacher had made every effort to improve student learning outcomes. This has become an obligation for all existing teachers, for example providing additional learning material for students in grade 6 so that they can better understand the learning material, so that the results of graduation scores can be improved properly.

Based on the results of research through interviews with teachers, especially homeroom teachers in grade 6, it was found that as the homeroom teacher of class 6 said that he had agreed with the principal and even other teachers were also planning lessons, even given directions by the principal in planning lessons . Before the implementation of the learning 
process is conveyed to students, of course the teachers first make a Learning Device Plan and the material presented is adjusted to the theme of each meeting related to the syllabus.

As long as they are teaching staff, that the evaluation of student learning outcomes is always carried out, and this is always given direction by the principal through teacher council meetings, both evaluating learning outcomes in mid-semester, per semester or every closing lesson. The school principal responded that teachers were able to carry out their duties as teachers and homeroom teachers in managing learning devices. The way that teachers do is through a direct approach to the subject, and ask about the difficulties experienced, and try their best to help these students so that the problems they face can be resolved.

Teachers rarely make approaches to foster students' interest in learning, especially by entertaining them. Because the fostered students are already in grade 6 , it is sufficient to provide an even explanation to all students so that they are always diligent in learning, especially regarding the achievement of grades and students' graduation In the learning process that the teachers have been doing so far, they have tried their best so that the learning conditions run conducive, students are active in listening and following the learning process, and it is hoped that students will be able to absorb every material presented. However, it must be understood that each student is different. This means that the quality of professional teachers who however convey the material, if students are not able to absorb and understand, the learning outcomes will vary.

As long as teachers are teaching staff, students are not given assignments every day. This is done so that students do not feel bored in following the learning process. Students must be relaxed and the learning process must be fun. Regarding the assessment, each student will be given a grade. This is done by teachers to provide motivation to students in the form of rewards in the form of values. Problems in the classroom generally occur when teachers deliver student learning materials that pay less attention to the learning material they convey. As for the way to overcome this, give a warning to the student to pay attention to the learning material he delivers.

During the learning process he conveyed, learning evaluation is always carried out, such as evaluating daily assignments done by students and providing assessments and evaluating learning outcomes that have been delivered either mid-semester, each semester or at the end of the learning process. Based on this evaluation, it can be seen whether the achievement of student learning outcomes has met the standard of assessment (KKM) or has not reached the KKM standard. If there are those who have not reached the KKM standard, these students will be given remedials and additional assignments so that the scores achieved are able to reach the KKM standards.

In line with this research, referring to relevant research has also strengthened studies in this research such as research conducted by Feri (2015) with the research title: "Teacher Learning Management at SD Negeri 1 Pelukan Pidie, Pidie Regency." The results of this study concluded that 1) Teacher learning planning has not been well programmed, there are teachers who have not been able to properly compile maps, develop theme networks, and compile syllabus as tools that must be prepared before compiling lesson plans; 2) Implementation of teacher learning is carried out based on the Unit Level Curriculum. The implementation is not optimal, there is still a lack of teacher knowledge about the procedures for implementing the learning effectively, and there are still low grade teachers who use 
subjects clearly and do not use themes; 3 ) The learning evaluation carried out is guided by the prepared lesson plans. Evaluation is carried out to improve teacher learning activities, forms of oral and written evaluation; and 4) Supporting factors for the supervision activities carried out by school principals to improve and foster teachers' abilities in implementing learning management. The obstacles, among others, in planning for teacher training, were due to the time, facilities and personnel available. Lack of training for teachers, inactivity of some teachers in cluster activities, seminars and activities to improve the teaching profession.

From the results of this relevant research, the researcher concludes that there are similarities and differences between this study and current research, namely both researching management in learning. Furthermore, the differences that exist in this study with current research are the places used as research.

Furthermore, research conducted by Sudrajat (2018) with the research title: "Performance Management of Primary School Teachers." The results of this study concluded that the implementation of the performance management of elementary school teachers who consider the main elements, supporting elements, and leadership functions of the principal is believed to be able to guarantee the effectiveness of the implementation of the process and learning outcomes and there are findings that the performance results are not optimal, which includes the curriculum as a source of competence, the meaning of competence by teachers, poor performance of teachers, completeness of learning tools, unclear teacher assignments, external factors that hinder teacher motivation, non-conducive working conditions, inadequate activities of supervision, professional development, and job evaluation, and limited sources of funding. Meanwhile, the principal has not yet functioned his leadership as a prime mover. From the results of this relevant research, the researcher can conclude that there are similarities and differences between this study and the current research, namely both researching about management, then the differences contained in this study and current research are the places used as research.

The next research was conducted by Muningsih (2015) with the title: "Classroom Management for Elementary School Teachers (Study of Learning Analysis on Students of SDN 02 Curup Timur)." The results of this study conclude that the class management of SDN 02 Curup Timur is not just an elementary school that prepares students to be able to continue to a higher level but also prioritizes student morals and worship than SDN 02 Curup Timur, which is an ordinary elementary school that prioritizes the curriculum set by the education office. From this relevant research, the researcher concludes that there are similarities and differences between the research and the current research, namely both researching the management of classroom teachers in elementary schools, then the differences in this study and the current research are the places used as research.

Fitria's research (2019), the results of his research show that 14 items do not meet the standards contained in Permen 24/2007, infrastructure facilities that do not meet the standards, namely: classrooms, library rooms, biology laboratory rooms, physics laboratory rooms, chemistry laboratory rooms, a computer laboratory room, a language laboratory room, a teacher room, an UKS room, a student organization room, a latrine, a warehouse, a circulation room, and a sports equipment room. Meanwhile, there are only 4 items in accordance with the standards contained in Permen 24/2007, namely: leadership room, administration room, prayer room, and counseling room. The principal as the head of the school has implemented an administrative function to improve the existing infrastructure in 
the school starting from the planning, coordinating, distribution, to accountability functions, by setting these functions it is hoped that these functions can optimize infrastructure in improving the learning process at SMA Negeri 9 Palembang. From this relevant research, the researcher concludes that there are similarities and differences between the research and the current research, namely both researching teacher management in the learning process, then the differences in this study with current research are the research places and subject studies that are the focus of research.

Furthermore, research by Kristiawan and Asvio (2018) entitled "Administrative Management of State Madrasah Tsanawiyah in Improving the Quality of Madrasah Education" found that education workforce administration is also well managed as evidenced by the presence of five master graduate teachers. Each teaching staff and educational staff work in accordance with their respective fields and expertise. The administration of facilities and infrastructure is also well managed, where every year there is a program to add equipment to support the teaching and learning process. In the administration of financing, MTs Negeri Padang Panjang receives assistance from the community in the form of physical assistance, the community provides donors for the development of madrasas in remote locales. In remote local development, there are already 6 rooms consisting of two units whose budget is from community participation at a cost of Rp. 900,000,000, -. From the research that supports this research, the researcher concludes that there are similarities and differences between the research and the current research, namely both researching teacher management, then the differences in this study and the current research are the research places and subject studies that are the focus of the research.

Based on theoretical studies, it is stated that school is one of the factors that determines student learning outcomes. The higher the student's learning ability and the quality of teaching at school, the higher the student's learning outcomes (Wasliman, 2014). According to Susanto (2016), the teacher is a very decisive component in the implementation of a learning strategy. Based on this opinion, it can be emphasized that one of the external factors that greatly affects student learning outcomes is the teacher. The teacher in the learning process plays a very important role. The role of teachers, especially for students at elementary school age, cannot possibly be replaced by other devices such as television, radio, and computers. Because students are developing organisms that need adult guidance and help.

The teacher is one of the most important elements in education. The quality of education is very much determined by the quality standards of teachers. Therefore, teachers need to improve their competence as stated in Law Number 14 of 2005 concerning Teachers and Lecturers. There are four competencies that teachers must fulfill, namely pedagogical competence, personality, professional competence and social competence. Then what about the teacher competency standards in Indonesia, do they meet the four competencies above. Of course there must be concrete steps to improve the quality and competence of teachers. The Ministry of Education and Culture realizes this and anticipates it by mapping teacher competency standards in Indonesia. Various trainings to improve teacher competence have been carried out, including teaching training adapted to current developments such as the use of technology.

The quality of teachers in teaching is one important aspect in efforts to improve the quality of life of the nation. This is because the source of teachers is the main force for all efforts to educate and learn the nation's children. This ability does not just exist, but is obtained from a 
long process of education and learning. With this process, we can get competent figures in their fields and then this changes the conditions of a school in general (Usman, 2012).

Efforts to improve teacher quality have been carried out by the government in various ways, including by providing block grants to schools as stimulant funds for implementing teacher professional development programs, forming subject teacher associations, forming teacher scientific forum organizations and publishing scientific journals. for teachers and teachers using the Subject Teacher Deliberation Program which has been in existence in almost every district. These various teacher quality development programs mainly aim to improve the abilities and skills of teachers in planning, developing, implementing and supervising the learning process to support improving the quality of education in each school unit (Sumardin, 2016).

Classroom management is an aspect of education that is often the main concern of prospective teachers, new teachers, and even experienced teachers who want students to learn optimally. The creation of such expectations is a study of classroom management. Because according to Djamarah and Zain (2010). Classroom management is a complex behavioral problem, and teachers use it to create and maintain classroom conditions in such a way that students can achieve teaching goals efficiently and enable them to learn.

Danim (2012) explains that it is in class that all aspects of learning meet and have a process. Teachers with all their abilities, students with all backgrounds and potentials, the curriculum with all its components, the method with its approach, the media with all its tools, the material with all its learning resources meet and interact in the classroom. Furthermore, learning outcomes are also determined by what happens in class. Therefore, it is proper that the classes in management are good, professional, continuous and sustainable. The positive relationship between teachers and students only builds with a positive attitude. Even though there are weaknesses in students, of course there are many advantages and it is far better to develop positive potential in students than to look for their weaknesses.

Teachers have a very big share of the success of learning in schools. Teachers are very instrumental in helping the development of students to achieve their life goals optimally. Every teacher enters the class, so at that time he also faces two main problems, according to Djamarah and Zain (2012), namely teaching problems and management problems. Teaching problems are efforts to assist students in achieving specific teaching goals directly, for example making lesson units, presenting information, asking questions, evaluating. Meanwhile, the problem of management is an effort to create and maintain conditions in such a way that the teaching and learning process can take place effectively and efficiently, for example strengthening members, developing teacher-student relationships, making productive group rules.

Danim (2012) further argues that classroom management is not only in the form of class arrangements, physical facilities and routines. Class management activities are intended to create and maintain classroom atmosphere and conditions. So that the teaching and learning process can take place effectively and efficiently. For example, providing reinforcement, developing teacher-student relationships and making productive group rules. Class management is needed because from day to day, even from time to time, the students' behavior and actions are always changing. Today students can study well and calmly, but not necessarily tomorrow. Yesterday there was healthy competition in the group, on the other 
hand, in the future the competition may not be healthy. Classes are always dynamic in the form of students' behavior, deeds, attitudes, mental and emotional. Effective classroom management performance according to Danim (2012) is reflected in the success of teachers in creating positive learning environments and empowering students to understand and be effective in engaging in the classroom management process.

In teaching and learning activities, of course, a teacher becomes the center of attention and is responsible for directing and guiding students in every learning process that takes place. Usman (2012) as a teacher class manager is responsible for maintaining the physical environment of the class so that it is always fun to learn and directing or guiding the intellectual and social processes in the classroom. Thus the teacher not only allows students to learn, but also develops the habit of working together with other students. The success of teachers in carrying out learning activities does not only require the ability to master subject matter, teaching strategies and methods, using media or learning tools. But the teacher must be able to provide or create conducive and pleasant learning situations and conditions that can be realized if the teacher is able to regulate the learning atmosphere, condition students to learn and take advantage of learning facilities or media and can control a pleasant atmosphere to achieve learning goals, this ability is called ability. manage the class.

Classroom management activities are activities that are closely related to learning activities and are very important in order to achieve an effective learning process. In the Big Indonesian Dictionary, the term management is defined as "administration, management". Meanwhile, what is meant by class is "level, space for learning at school". So that class management is translated briefly as a process of organizing or managing a room where teaching and learning activities are carried out. Classroom management is needed because from day to day and even from time to time, the behavior and actions of students are always changing. Today students can study well and calmly, but not necessarily tomorrow. Yesterday there was healthy competition in the group, in the future the competition may not be healthy. Therefore, in managing the classroom, a teacher certainly needs to pay attention to how to create an appropriate learning climate, organize learning spaces, and manage teaching and learning activities so that teaching and learning activities can run according to predetermined goals.

According to Wahyuningrum (2014), there are three core activities in classroom management, namely as follows: 1) creating the right learning climate including warmth and enthusiasm, challenges, variety, flexibility, emphasis on positive things, and cultivation of self-discipline. 2) arranging the learning room including the seating arrangement of students, the arrangement of educational media, the provision of aromatherapy. and 3) managing teaching and learning activities including opening and closing lessons skills, explaining skills, questioning skills, reinforcement skills, learning media skills, small group discussion guiding skills, class management skills, variation skills and individual and small group teaching skills.

\section{Conclusion}

Based on the results of the study, it can be concluded that the function of classroom teacher education management in improving the learning outcomes of SD Negeri students in Babat Toman District, Musi Banyuasin Regency can be said to be good and in accordance with the duties carried out in carrying out the learning process. The teacher can be said to have been 
able to plan the learning process. The teacher can be said to have been able to carry out the learning process. Teachers can be said to have been able to evaluate learning outcomes. The teacher can be said to have been able to follow up on the learning results that have been delivered. Teachers can be said to have been able to provide guidance and counseling to students, especially in helping students' learning difficulties.

\section{E. Acknowledgement}

We thank to the principal of SD Negeri 3 Babat Toman, Rector Universitas PGRI Palembang who gave us the support to do this wonderful project. This project was funded independent. We would also like to thank our friends in Educational Management who helped us a lot in finalizing this project within the limited time frame.

\section{References}

Danim, S., \& Danim, Y. (2012). Administrasi Sekolah dan Manajemen Kelas [School Administration and Classroom Management]. Bandung: Pustaka Setia.

Djamarah, S. B. (2010). Metode dan Statistika Penelitian [Research Methods and Statistics]. Jakarta: Rajawali Pers.

Djamarah., Syaeful, B., \& Aswan, Z. (2010). Strategi Belajar Mengajar [Teaching and Learning Strategies]. Jakarta: Rineka Cipta.

Feri, N. (2017). "Manajemen Pembelajaran Guru Pada SD Negeri 1 Pelukan Pidie Kabupaten Pidie [Teacher Learning Management at SD Negeri 1 Pelukan Pidie, Pidie Regency]". Jurnal Manajer Pendidikan, Volume 9, Nomor 5, November 2015, hlm. 699-703.

Fitria, H. (2019). "Manajemen Sarana Prasarana dalam Meningkatkan Proses Pembelajaran. Prosiding Seminar Nasional Pendidikan Program Pascasarjana Universitas PGRI Palembang [Infrastructure Management in Improving the Learning Process. Proceedings of the National Education Seminar for the Postgraduate Program at the PGRI University of Palembang] 12 Januari 2019”.

Hamid. (2015). Kemampuan Dasar Mengajar: Konsep Dasar Teori dan Praktek [Basic Teaching Skills: Basic Concepts of Theory and Practice]. Bandung: Alfabeta.

Kristiawan, M., \& Asvio, N. (2018). "Pengelolaan Administrasi Madrasah Tsanawiyah Negeri dalam Meningkatkan Kualitas Pendidikan Madrasah [Administrative Management of State Madrasah Tsanawiyah in Improving the Quality of Madrasah Education]". Kelola: Jurnal Manajemen Pendidikan 5(1).

Kurniawan, S. (2016). Pendidikan Karakter [Character building]. Yogyakarta: AR-Ruzz Media.

Law Number 14 of 2005 concerning Teachers and Lecturers

Moleong, L. (2011). Metodologi Penelitian Kualitatif [Qualitative Research Methodology]. Bandung: Remaja Rosdakarya. 
Journal of Social Work and Science Education

Volume 1 (2) 2020

E-ISSN: 2723-6919 P-ISSN:2746-0827

Muningsih. (2015). "Manajemen Kelas Guru Sekolah Dasar (Studi Analisis Pembelajaran Pada Siswa SDN 02 Curup Timur) [Classroom Management for Elementary School Teachers (Study of Learning Analysis in SDN 02 Curup Timur Students)]". Jurnal. Manajer Pendidikan, Volume 9, Nomor 5, November 2015, hlm. 699-703.

Purwanto, N. (2014). Administrasi dan Supervisi Pendidikan [Education Administration and Supervision]. Jakarta: Rineka Cipta.

Rizaldi, A. (2014). Dari Guru Konvensional Menuju Guru Profesional [From Conventional Teachers Towards Professional Teachers]. Jakarta: Grasindo.

Sani, B. (2017). Kompetensi Pedagogik, Teori dan Praktik Untuk Peningkatan Kinerja dan Kualitas Guru. Jakarta: Kata Pena.

Sudaryono. (2012). Metode Penelitian Kualitatif [Qualitative Research Methods]. Bandung: Remaja Rosdakarya.

Sudrajat. (2018). "Manajemen Kinerja Guru Sekolah Dasar [Primary School Teacher Performance Management]. Bandung: Universitas Pendidikan Indonesia". Jurnal Administrasi Pendidikan Vol. XXV No.1 April 2018, hal. 104-119.

Sugiyono. (2015). Metode Penelitian Pendidikan, Pendekatan Kuantitatif, Kualitatif dan $R$ \& $D$ [Educational Research Methods, Quantitative Approaches, Qualitative and $R \&$ D]. Bandung: Alfabeta.

Sukadi. (2012). Guru Powerfull, Kunci Sukses Menjadi Guru Efektif [Powerful Guru, Key to Success in Becoming an Effective Teacher]. Bandung: Kolbu.

Sumardin. (2016). Pengembangan Profesionalisme Guru Berbasis MGMP Model dan Implementasinya [MGMP-Based Teacher Professionalism Development Model and Its Implementation]. Yogyakarta: Budi Utama.

Susanto, A. (2016). Implementasi Pembelajaran di Sekolah Dasar [Implementation of Learning in Primary Schools]. Jakarta: Kencana Prenada Media Group.

Usman, M. U. (2012). Menjadi Guru Profesional [Become a Professional Teacher]. Bandung: Remaja Rosdakarya.

Wahyuningrum. (2014). Pengelolaan Kelas di Sekolah Dasar [Classroom Management in Primary Schools]. Bandung: Alfabeta.

Wasliman, I. (2014). Problematika Pendidikan Dasar [Basic Education Problems]. Bandung: PPs-Universitas Pendidikan Indonesia. 